\title{
Gender Matters
}

\section{Women in the Australian Screen Industry}




\section{Gender Matters - Women in the Australian Screen Industry}

\section{Context}

Who is telling Australian stories? And whose stories are being told? Are women adequately represented in key creative roles and positions of influence in the Australian screen industry? If not, why not, and what can we do about it?

While this paper will look at women in the screen industry, Screen Australia recognises that other groups may also be under-represented in front of and behind the camera. In conjunction with the national broadcasters, it is working on a new study on cultural diversity in TV drama, which it expects to release in 2016.

\section{Introduction}

\section{Are women properly represented?}

In May this year, Screen Australia updated statistics on key screen credits by gender to coincide with the Women in Film issue of Lumina, which injected new energy into debates on this issue due to continued poor levels of female representation (see page 5). Screen Australia's analysis of applications and funding decisions over the past two years has revealed that the proportion of women attached in key roles to all applications has been matched by the proportion of women attached to successful applications. In the context of feature film production investment, 47 per cent of producers attached to both applications and funded projects were female. In feature development, a strong bias towards women has been demonstrated across all creative roles. Notably, 47 per cent of producers attached to applications were female, compared to 59 per cent of producers for funded projects. In the context of the writer, 32 per cent of applicant writers were female and 40 per cent of funded writers. Further detail is available in Appendix 2.

The recent success of projects such as The Dressmaker has made a strong commercial case for a greater number of independent films helmed by women for a female cinema-going audience. Other projects that can boast a full female creative complement, (writer, director, producer and protagonist) including Sherpa, Gaby Baby and Looking for Grace, have all made a significant cultural and creative impact.

TV tends to do much better than features in its representation of women on screen, where many long-running series feature strong female protagonists. However, this gender diversity is less marked behind the camera. Multiplatform content tends to show tremendous diversity of content and content creators, as do short films and 'entry level' opportunities. However, many women fail to make the leap from emerging practitioner to sustained careers and positions of influence, which leads to under-representation. 


\section{Gender Matters - Women in the Australian Screen Industry}

\section{Why does it matter?}

There are many good reasons to act on this issue. Part of Screen Australia's remit is to support the creation of culturally relevant content that resonates with a broad range of audiences. To achieve this goal, Australian screen stories should reflect the diversity of experiences and perspectives in contemporary Australian society. For its part, Screen Australia needs to ensure that the content it supports is relevant to audiences. However, those audiences are far more diverse than much of the current content would suggest.

There are also good commercial reasons to address this issue. Women of all ages spend more time viewing television than men ${ }^{1}$ and while women over the age of 50 are big consumers of feature films at the cinema ${ }^{2}$, Australian films targeting this demographic are scarce.

\section{What should we do?}

Issues of gender bias have been approached in various ways over time by Screen Australia and its predecessor agencies, some of which are summarised in this document. This is a complex issue that is not confined to the screen industry or to Australia. An overview of the attempts to address it in Sweden and the UK are outlined in Appendix 3.

Understanding the barriers facing women is an essential component to any effective long-term policy response. Screen Australia can play a role in creating opportunities for female creatives.

Initial analysis of the proportion of projects with at least 50 per cent female creative teams ${ }^{3}$ shows that projects with women across a range of creative roles represent 58 per cent of all funded projects. However our challenge is in the critical area of production where only 29 per cent of feature projects and 44 per cent of TV drama projects have at least 50 per cent female representation across key roles. Further detail is available in Appendix 1.

In addition, we can support the industry as it addresses the barriers facing women in the screen sector. However, we should also recognise that we do not hold all the levers for change. Therefore, a holistic, long-term approach that focusses on the creative team, rather than the individual, will be needed to support practitioners from a range of backgrounds to develop the infrastructure that will create sustainable and successful careers and businesses.

\footnotetext{
${ }^{1}$ http://www.screenaustralia.gov.au/research/statistics/audiencesfreetvviewing.aspx

${ }^{2}$ http://www.screenaustralia.gov.au/research/statistics/audiencescinemaagexgender.aspx

${ }^{3}$ Screen Australia defines the 'creative team' roles for feature films and TV drama as: writer, producer, director and protagonist. For documentaries: writer, producer and director.
} 


\section{Gender Matters - Women in the Australian Screen Industry}

\section{Women in the industry - are they under-represented?}

While women represent just over 50 per cent of the population ${ }^{4}$, are well represented in higher education ${ }^{5}$ and make up 46 per cent of the workforce ${ }^{6}$, they are still under-represented in senior levels of management across most industries in Australia. According to the Australian Institute of Company Directors, the proportion of women on ASX 200 company boards is around 20 per cent (July 2015). ${ }^{7}$

The percentage of women on boards of the five free to air networks and Foxtel is marginally better than in ASX 200 companies: of the 51 board members, 26 per cent are women (September 2015). ${ }^{8}$ In the free-to-air broadcasting sector, the proportion of women in the management teams is slightly better: around 30 per cent, according to the broadcaster websites. The proportion of women in the management teams of Australia's largest TV production companies is also around 30 per cent $^{9}$, and no television networks are helmed by women.

Looking at women's involvement in the Australian production industry overall, the picture is also discouraging. According to the latest census, in 2011 women comprised 36 per cent of people employed in the film and video production sector and 29 per cent in the post-production sector.

The proportion of women in both sectors combined was 35 per cent. This share has declined since 1971, when the proportion of women in film, video and PDV was 36 per cent. In contrast, the proportion of women in the broadcasting industry increased from 28 per cent to 44 per cent over the same period.

The number of women directing feature films is another field characterised by female underrepresentation. This is reflected in the films released theatrically in Australia: of the top 250 films from any country at the Australian box office in 2014, only 8 per cent were directed by women. Of the 21 Australian films in the top 250, 14 per cent were directed by women. Overall, 37 Australian feature films and documentaries were released in cinemas last year, and only 16 per cent were directed by women.

\footnotetext{
${ }^{4}$ Australian Bureau of Statistics (ABS), Australian Demographic Statistics, March 2015 (cat. no. 3101.0)

${ }^{5}$ Australian Bureau of Statistics (ABS), Gender Indicators, Australia, August 2015 (cat. no. 4125.0)

${ }^{6}$ Workplace Gender Equality Agency, Gender workplace statistics at a glance August 2015

https://www.wgea.gov.au/sites/default/files/Stats_at a Glance.pdf

${ }^{7}$ http://www.companydirectors.com.au/Director-Resource-Centre/Governance-and-Director-Issues/Board-

Diversity/Statistics

8 Broadcaster websites:

https://www.foxtel.com.au/about/the-company/meet-the-board.html

http://www.nineentertainment.com.au/board-of-directors.aspx

http://www.sevenwestmedia.com.au/about-us/board-of-directors

http://tenplay.com.au/corporate/about/directors/

http://about.abc.net.au/who-we-are/the-abc-board/

http://www.sbs.com.au/aboutus/board-of-directors

${ }^{9}$ Endemol, Screen Time, Fremantle Media, Beyond websites
} 
Women working in key creative roles

\section{Documentaries 1988-2014}
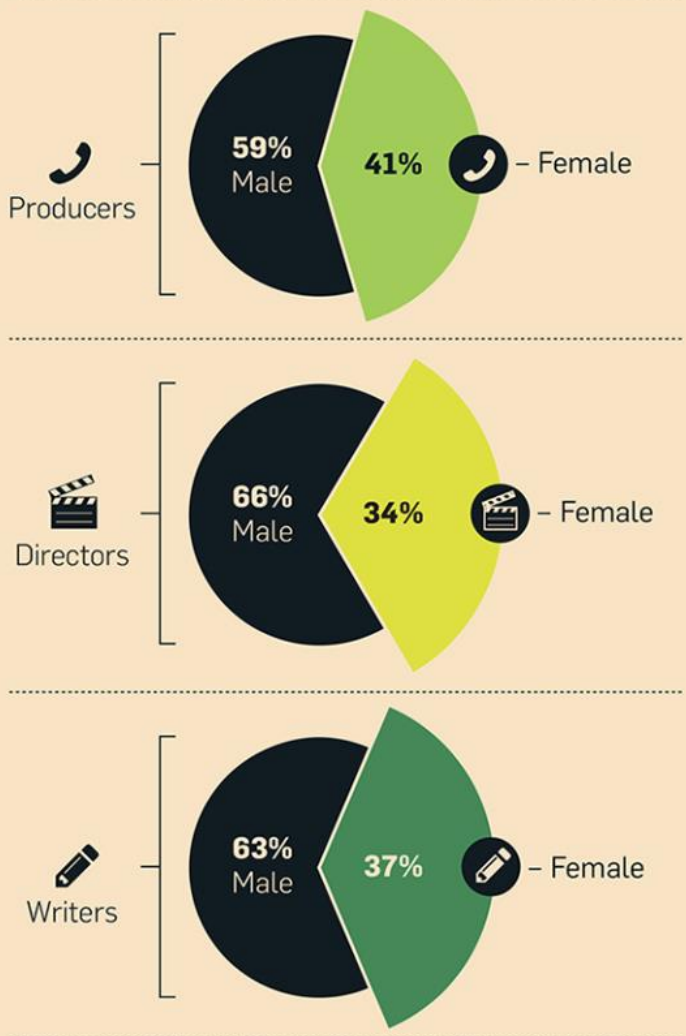

\section{Female $\%$ of}

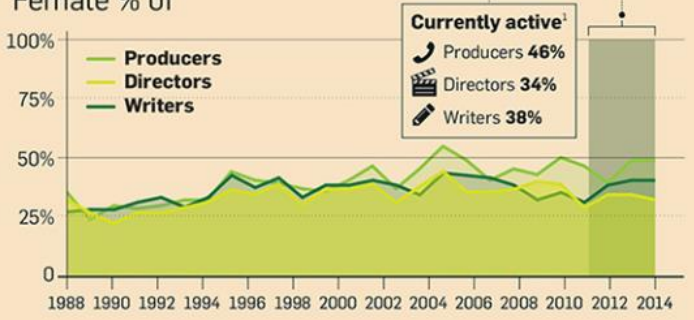

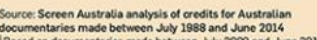

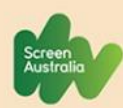

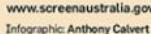

Film 1970-2014
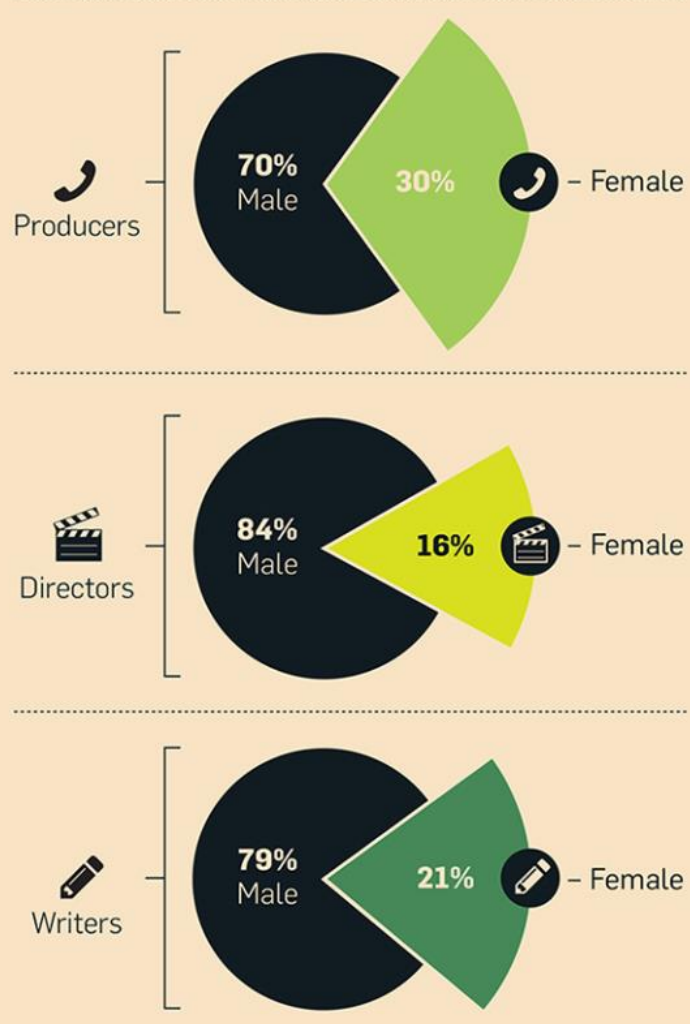

Female \% of

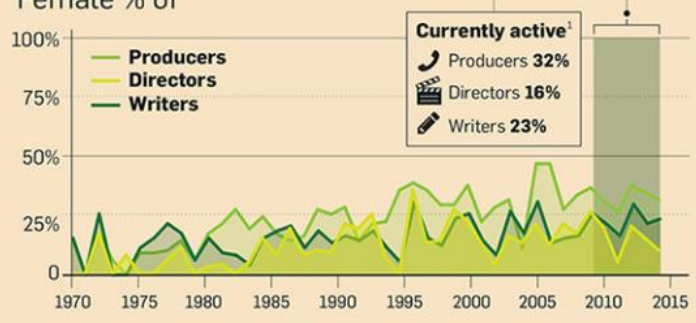

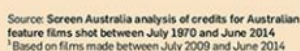

Data released by Screen Australia May 2015 


\section{Gender Matters - Women in the Australian Screen Industry}

\section{On-Screen Representation: Television}

Recent Australian drama series provide more diverse representations of women than in former years. On free-to-air TV, this includes Offspring, Janet King, Love Child, Redfern Now, A Place to Call Home, Dance Academy and Anzac Girls.

On subscription TV, female-centric Australian dramas Wentworth and Top of the Lake have been commercially and critically successful both at home and overseas. All these dramas have women in key creative roles such as writer, director or producer.

\section{Features}

A strong relationship between the gender of feature filmmakers and their protagonists was identified by Lisa French in her analysis of projects supported by Screen Australia, ${ }^{10}$ with films made by male directors featuring a female character or subject only 24 per cent of the time, compared to 74 per cent for films with women directors. This suggests that the gender imbalance in key creative roles has a significant impact on the way in which women are represented in Australian feature films.

Gender Bias Without Borders, a US-originated research report exploring the visibility and nature of female depictions in films worldwide, was published in 2014. ${ }^{11}$ The study analysed gender roles in the top 10 most popular domestic films ${ }^{12}$ across the 11 largest box office markets between 2010 and 2013. Australia was included in the study, which evaluated every speaking or named character in the films.

Ten films is admittedly a small sample; however, these films are significant because they were the Australian films seen by the most people. Female characters represented 30 per cent of the total 386 characters in the Australian films, and 40 per cent of lead or co-lead characters. There were stark differences between how men and women were represented in these films from the perspectives of employment status, profession, cultural background and sexualisation of the characters; women tended to be objectified or marginalised. Behind the camera on these 10 Australian films, only one of the directors, a third of the writers and 30 per cent of the producers were female.

\footnotetext{
${ }^{10}$ Associate Professor Lisa French, Does Gender Matter? Lumina Issue 14, p.142

${ }^{11}$ Gender Bias Without Borders, 2014 http://seejane.org/wp-content/uploads/gender-bias-without-bordersfull-report.pdf

12 The top 10 most popular Australian films used in this study were: Red Dog; The Sapphires; Happy Feet Two; Bran Nue Dae; Kath and Kimderalla; Legend of the Guardians: Owls of Ga'Hoole; The Kings of Mykonos: Wog Boy 2; The Cup; Goddess; Return to Nim's Island.

For a full list of the films used in each market see Gender Bias Without Borders, 2014 http://seejane.org/wpcontent/uploads/gender-bias-without-borders-full-report.pdf
} 


\section{Gender Matters - Women in the Australian Screen Industry}

\section{What are the barriers and challenges that women face?}

The proportion of female film school graduates is much higher than the percentage of female key creatives associated with theatrically released Australian films, and much closer to the share of the Australian population. AFTRS reports that between 1973 and 2015, of all graduates in screenwriting, production and directing, 52 per cent were men and 48 per cent women. ${ }^{13}$ Other Australian film schools report a similar gender breakdown overall; however, some film school representatives have noted that cinematography students are significantly more likely to be male. ${ }^{14}$ The cause of the imbalance does not appear to lie in education or training; rather, it lies in what happens after education ends.

\section{Career progression}

The barriers to female participation and progress within the screen industry vary according to career stage, industry sector and role. Screen Australia has canvassed views and experiences in this area with women at a range of career stages and key influences across a range of sectors of the industry. Five overarching factors have emerged as barriers that can impact women creatives in various roles over the course of their career.

\section{Key Decision Makers}

Recent articles in the media have attributed the gender imbalance to bias on the part of key industry decision makers. These include local distributors, investors, network executive producers and international A-list festival programmers. They have argued that these decision makers are overwhelmingly male and as a result, are less likely to back projects that have female key creatives attached or which provide opportunities for emerging female talent. On the other hand, many female creatives have given examples to Screen Australia of an influential male providing support. This support has translated into positive outcomes for the career progression of individual female creatives, which has in turn contributed to the development of female-centred storytelling on TV.

\section{Male dominance in related industries}

Industry stakeholders often cite how experience in related industries assists creatives to gain skills, build a professional profile and a body of work, and generate an income between narrative screen projects. Advertising was highlighted as an important industry for emerging directors both as a pathway to directing feature films and as way to generate income in between film projects. Many stakeholders have argued that female directors face significant discrimination in the advertising industry ${ }^{15}$. The theatre sector, also dominated by men at the expense of female talent, was noted as a place where writers can develop their craft, attract the attention of key decision makers and generate income. Statistics released by the Australia Council in 2012 revealed that between 2001

\footnotetext{
${ }^{13}$ Cara Nash, Film School Bridging the Gap, FilmInk, September 2015

14 Ibid.

${ }^{15}$ http://mumbrella.com.au/mad-men-industry-women-228290
} 


\section{Gender Matters - Women in the Australian Screen Industry}

and 2011, 25 per cent of productions at the eight major theatre companies were directed by a woman and 21 per cent were written by a woman. ${ }^{16}$

\section{Time out of the workforce/childcare}

Time out of the workforce to raise children is a barrier to career progression that primarily affects women. The freelance nature and intensive, irregular hours of much employment in the screen industry exacerbates the difficulty of balancing family responsibilities and work. Access to paid maternity leave is often not an option, and freelance employers are not obliged to offer formal return to work. Any time out of the workforce during this critical time can penalise filmmakers' abilities to leverage opportunities and take the next steps in their careers. In addition, those with childcare responsibilities (often women) - even if not taking time out of the workforce - can be regarded as less flexible than those without childcare responsibilities (often men).

\section{Lack of self-belief}

Anecdotal evidence indicates that women are far more likely than their male counterparts to underestimate and undersell their skills and abilities. ${ }^{17}$ The effect of this is that women can be perceived to lack confidence, and are less likely to push themselves forward.

\section{Pay equity}

Australia's gender pay gap is 17.9 per cent - the highest it's been for two decades. The ABS data show that this pay gap is larger in the private sector ${ }^{18}$, and that gender differences in pay, for the same job with the same qualifications, begin the moment a student graduates.

This pattern continues in the screen industry. According to the Census of Population and Housing conducted in August 2011, men working in the production and post-production sectors are much more likely than women to earn an income in the highest bracket of $\$ 65,000$ and less likely to earn an income in the lowest brackets of less than $\$ 31,199$.

16 http://www.australiacouncil.gov.au/workspace/uploads/files/research/women-in-theatre-april-201254325827577ea.pdf

${ }^{17}$ Andrena Finlay, Resilience \& Focus, and Lauren Edwards, Horrific and Hilarious, 2015, Lumina Issue 14

18 Workplace Gender Equality Agency, Gender pay gap statistics, September 2015 https://www.wgea.gov.au/ 
2011: Income Distribution by Sex: Film and Video Production and Post-Production Services

\begin{tabular}{|c|c|c|c|c|c|c|c|}
\hline Income Bracket & $\begin{array}{c}< \\
\$ 20,800\end{array}$ & $\begin{array}{c}\$ 20,800- \\
\$ 31,199\end{array}$ & $\begin{array}{c}\$ 31,200- \\
\$ 41,599\end{array}$ & $\begin{array}{c}\$ 41,600- \\
\$ 51,999\end{array}$ & $\begin{array}{c}\$ 52,000- \\
\$ 64,999\end{array}$ & $\begin{array}{c}\$ 65,000 \\
+\end{array}$ & $\begin{array}{c}\text { Not } \\
\text { stated }\end{array}$ \\
\hline \multicolumn{8}{|l|}{ PRODUCTION } \\
\hline Men & $10 \%$ & $7 \%$ & $10 \%$ & $12 \%$ & $14 \%$ & $46 \%$ & $1 \%$ \\
\hline Women & $11 \%$ & $9 \%$ & $11 \%$ & $13 \%$ & $14 \%$ & $39 \%$ & $1 \%$ \\
\hline \multicolumn{8}{|c|}{ POST PRODUCTION } \\
\hline Men & $10 \%$ & $6 \%$ & $11 \%$ & $13 \%$ & $13 \%$ & $47 \%$ & $1 \%$ \\
\hline Women & $10 \%$ & $11 \%$ & $11 \%$ & $16 \%$ & $14 \%$ & $37 \%$ & $2 \%$ \\
\hline
\end{tabular}

Compiled by Screen Australia using unpublished data from the Australian Bureau of Statistics (ABS), Census of Population and Housing, 2011. Adjustments have been made to figures by the ABS to avoid the release of confidential data. Figures may not total exactly due to rounding.

Although women earn less, they are more likely to have a qualification: 72 per cent of women in film and video production and post-production services had a qualification, compared to 65 per cent of men.

\section{Qualification by Sex: Film and Video Production and Post-Production Services}

\begin{tabular}{|l|c|c|c|c|}
\hline & $\begin{array}{c}\text { Bachelor Degree } \\
\text { or Higher }\end{array}$ & $\begin{array}{c}\text { Other } \\
\text { Qualification }\end{array}$ & Unknown & No Qualification \\
\hline PRODUCTION & $37 \%$ & $27 \%$ & $3 \%$ & $33 \%$ \\
\hline Men & $51 \%$ & $21 \%$ & $2 \%$ & $25 \%$ \\
\hline Women & $46 \%$ & $26 \%$ & $2 \%$ & $26 \%$ \\
\hline POST PRODUCTION & $53 \%$ & $20 \%$ & $4 \%$ & $23 \%$ \\
\hline Men & & & & \\
\hline Women & & & & \\
\hline
\end{tabular}

Compiled by Screen Australia using unpublished data from the Australian Bureau of Statistics (ABS), Census of Population and Housing, 2011. Adjustments have been made to figures by the ABS to avoid the release of confidential data. Figures may not total exactly due to rounding.

\section{Gaps in the pathway leading to production}

The statistics on the gender of creatives attached to applications and funding outcomes suggest that Screen Australia does not penalise projects helmed by women.

A significant proportion of the key creatives attached to applications for Talent Escalator programs are female, demonstrating that there are substantial numbers of women who have had success with short films and who want a career in the screen industries. This suggests a major gap in the pathway between short form storytelling and longer form and a failure of the system to accommodate women. 


\section{Gender Matters - Women in the Australian Screen Industry}

In addition, the proportion of female creatives attached to applications for the Feature Film Development Fund (now the Story Fund) is higher than for production investment applications for feature films. This may also indicate that the marketplace is not recognising the economic value of cinema-going female audiences, and how female creatives could be better positioned to reach these, or is unwilling to take a risk on females operating in traditionally male genres (eg. The Babadook).

\section{Screen Australia precedents and actions to date}

There are precedents for targeted Government support for gender and cultural diversity in the Australian screen industry.

In 1976 the Australian Film Commission established the Women's Film Fund, which provided direct financial support for development, production and training programs. This Fund progressed the careers of many women who have been successful in the industry since then. However, it was criticised at the time for 'ghettoising' women's film and implying that the main funding strands were intended for men.

In 1990 the AFC replaced the Women's Film Fund with the Women's Program. This moved away from direct investment in production to support for professional development, research and policy development. The goal was to enhance women's participation and career advancement in the film industry.

Screen Australia's actions to date in relation to female practitioners have included:

- Regularly-updated statistics on women's participation in key creative roles.

- Strengthening women's relationships with key decision makers.

- Reaching out to emerging female creatives who have financed and completed significant projects without Screen Australia support.

- Support through Talent Escalator programs, including special initiatives on writing strong female characters.

- Data on audiences broken down by gender.

- Ongoing consultation with stakeholders at all levels of the industry.

- Diversity outcomes attached to Event Partnership Funding (e.g. for workshops, master classes, co-sponsored professional development programs).

- Agreement with the ADG to reserve 75 per cent of Screen Australia-supported attachments for gender and culturally-diverse directors.

- 50 per cent of successful placements through our Enterprise People program have been women.

We have the research, and some groundwork, now it's time for further action. 


\section{Gender Matters - Women in the Australian Screen Industry}

\section{Screen Australia's Five Point Plan}

Screen Australia recognises that, to make a real difference to women's participation and success in the industry, there needs to be a holistic, integrated approach to people, projects and business. We are aiming to ensure our production funding is targeted to creative teams (writer, producer, director and protagonist) that are at least 50 per cent female by 2018 year end. The Five Point Plan seeks to implement practical and effective measures in order to create:

- business infrastructure that is sustainable and self-generating;

- ongoing professional development opportunities; and

- viable career pathways.

As the name would suggest, there will be five elements to the plan, which will be refined and further developed under the guidance of an expert Gender Matters Taskforce chaired by Screen Australia's Deputy Chair, Deanne Weir, and will include some of the industry's leading advocates for female representation. Two are more instant measures, and three are longer term:

\begin{tabular}{|c|c|}
\hline Short-term measures & Longer-term measures \\
\hline 1. The Women's Story Fund & 3. Placements for Women \\
\hline 2. Enterprise Women & 4. Distribution Guarantee Support \\
\hline & 5. Assessment criteria changes \\
\hline
\end{tabular}

The plan includes an immediate \$3 million 'jump-start' program (Points 1 and 2) to ensure practitioners and projects are production-ready within two years. The longer-term measures include a further $\$ 2$ million of support for placements, distribution, packaging and marketing and industry networking (Points 3, 4, and 5), which will help to ensure that there is a pool of female-driven projects in the future.

\section{The Women's Story Fund}

How: The Women's Story Fund is an initiative to stimulate awareness and increased industry activity around storytelling by, potentially about, and for women. The fund will be open, flexible and responsive to new projects at concept stage. Concepts may be of any genre (sci-fi, thriller, horror, comedy), of any budget size, for any identified audience and for any platform. Through the fund, Screen Australia will support bold, original and compelling story concepts into development and towards production.

The fund will be designed to enable creatives, from emerging to experienced, to develop a project that will be a strategic next step in a career. It will allow for experienced women creatives to evolve 


\section{Gender Matters - Women in the Australian Screen Industry}

and reinvent their storytelling voices across other platforms or enable women who have been out of the industry to re-enter and flex their creative muscles. As the eligibility is open, the fund will also create the opportunity to identify new storytelling voices.

Who: There are very few eligibility restrictions proposed.

The project must not have received funding previously from Screen Australia or any other agency. It must satisfy a 3 Tick Test, having at least three of the following elements:

- Female director

- Female writer

- Female writer/director (counts for 2 elements)

- Female protagonist

- Female producer

Why:

- to increase the number of women directors, writers and producers working in the screen industry

- to increase the number of projects generated, produced and /or told by women

- to increase the number of screen stories about women and, by extension, for female audiences.

What:

- up to $\$ 100,000$ for feature films to move a project from concept towards production. This would include multiple stages of development with a number of delivery milestones built into the development plan. Screen Australia will also fund teams from concept to first draft and possibly second draft. Projects that are successful in gaining feature funding through the Women's Story Fund are eligible to apply to other Screen Australia funding programs.

- up to $\$ 50,000$ for scripted television to develop an inventive concept into a series bible, series outline, first draft pilot script, first episode script, possibly including proof-of-concept materials.

- up to $\$ 50,000$ for scripted online and interactive projects to enable teams to realise their unique and compelling story concepts in any genre on any platform.

Depending on the project development plan and the experience and skills of the applicant/team, an application could be made for anything that will help move the project toward production. This might include draft costs, but could also include the production of test scenes, workshops with actors, attendance at markets, pitch materials, proof of concept, research etc.

To be competitive for funding, it is proposed that projects will need to demonstrate a compelling concept and distinctive storytelling voice that will connect with audiences, and a convincing 


\section{Gender Matters - Women in the Australian Screen Industry}

development plan. The teams should also evidence a skillset that is appropriate to the scale and vision of the project.

When: The call-out is proposed to occur alongside Enterprise Women, ideally before the end of quarter one, 2016.

\section{Enterprise Women}

How: Enterprise Women is a flexible and responsive proposal that aims to empower and increase the participation of women in the screen industry by creating business and industry infrastructure that is sustainable and self-generating. It also proposes to generate viable career pathways and ongoing professional development opportunities for industry renewal.

Who: Applications could come from industry guilds, industry organisations and companies that have the capacity to implement and deliver on their proposal.

Why: Screen Australia believes that there is unmet demand for female-generated stories. This measure will help companies meet that opportunity and address the demand.

What: Applications could be for up to $\$ 250,000$ for a proposal that engages with (but is not limited to) the following objectives to:

- create sustainable careers for women in the screen industry.

- grow businesses that prioritise female leadership and are focused on female creatives and/or female stories.

- $\quad$ produce stories generated by women, about women and for women (platform neutral).

- target professional development opportunities for women in creative practice and/or business.

- provide support for business models that embrace the economic potential presented by developing, producing and delivering stories by women, about women (but not limited to) and for female audiences.

- fill gaps in career development pathways between short film and multiplatform through to feature film and TV, and which also address the challenges faced by female directors getting a second feature up.

Although not prescriptive, it is proposed to encourage applications that will create opportunities in the following areas:

- mentorship schemes

- placements (creative and/or business oriented. Placements with distribution companies are encouraged)

- slate development

- workshops, seminars, events 


\section{Gender Matters - Women in the Australian Screen Industry}

- business growth and strategy, including pathways to audience

When: The call-out is proposed to occur alongside The Women's Story Fund, ideally before the end of quarter one, 2016.

Sitting alongside the immediate jump-start provided by the first two points are a number of pillars designed to provide ongoing support to address the key barriers and challenges to women pursuing successful careers in the screen industry. Barriers include: securing a first credit; moving beyond a first credit; networking opportunities and the time and experience to build a sustainable career.

\section{Attachments for women / Reverse mentoring- Production investment}

How: It is proposed that Screen Australia require a female attachment to projects when the agency provides over $\$ 500,000$. This could be an above-the-line position, an attachment to a Head of Department, or a reverse attachment where an experienced director is attached to provide on-the job coaching and mentoring to an emerging female director. These attachments/placements do not replace crew roles but should offer a meaningful learning and experiential opportunity. To be eligible to apply for production investment, Screen Australia will require the placement/attachment to be accommodated in the submitted budget.

Why: Although there are a number of attachment and placement schemes in operation, only the ADG attachment scheme has a commitment to 75 per cent of placements being gender and culturally diverse (a condition of Screen Australia funding for the program). The scheme aims to provide valuable production experience for women who want to break into long-form storytelling whether as creatives or crew. It further aims to create the opportunity to extend networks and professional relationships that assist with careers.

Who: Emerging and mid-level career female creatives and female crew that need to extend their production experience and/or to take the next step in establishing an ongoing career. Screen Australia will work with the guilds to create a pool of talent that production companies can draw from.

NOTE: Screen Australia will work actively with all television projects to encourage and potentially require series running longer than six episodes to employ a female director on at least one episode. The concept of reverse mentoring in this context may be particularly applicable.

What: Scripted drama projects that receive Screen Australia funding over $\$ 500,000$ as investment.

When: To begin in the 2016-17 financial year.

\section{Matched Distribution Guarantee support}

How: Screen Australia could offer up to $\$ 300,000$ for packaging, marketing and promotion for local 


\section{Gender Matters - Women in the Australian Screen Industry}

and/or international territories. Potentially this amount could be matched against a distributor's advance against ANZ receipts. The project would then be assessed in the usual way. Amounts should be commensurate with the scale of the project and the release.

The aim of this program is to encourage producers to work in close partnership with distributors on female-driven projects, to shape and market the film ensuring that strategies to connect with audiences are a primary and early part of the conversation. It could also give distributors the comfort that adequate resources will be quarantined to help the film reach its target audience.

Who: For projects that are successful in gaining a Screen Australia grant or investment and satisfy the 3 Tick Test (set out in the Women's Story Fund).

Why: To encourage producers to work in close partnership with distributors on female-driven projects; to shape and market the film, and ensure that strategies to connect with audiences are a primary and early part of the conversation about the project

What: This aims to encourage distributors to support female-driven projects earlier in the production stage, giving them the comfort that adequate resources will be quarantined to help the film reach its target audience.

When: Screen Australia proposes to run a pilot program in 2016/17, and expects that approximately three films per year will benefit from matched distribution guarantee funding.

\section{Assessment criteria across Screen Australia funding programs}

How: Screen Australia will change its assessment criteria to encourage projects that promote gender and cultural diversity and remove barriers that women who take time out of the workforce may face when applying for funding. In particular, Screen Australia will add the gender and cultural diversity of the team as an additional point of consideration. In addition, Screen Australia will remove the eligibility criteria across our documentary and Indigenous funding program strands that require credits to be less than 10 years old.

Why:

- To encourage projects that promote gender and cultural diversity.

- To address additional barriers that women who take time out of the workforce may face when applying for documentary production funding.

Who: Eligibility will still be assessed on merit, but preference may be given to those who have gender and cultural diversity in their teams.

When: Effective immediately. 


\section{Appendix 1 \\ Screen Australia analysis of women in creative teams 2013/14 and 2014/15}

The following data analyses all applications and successful applications to Screen Australia's funding programs over the last two financial years. It examines the incidence of women across key creative roles, identifying projects that have at least 50 per cent female 'creative teams'.

The 'creative team' roles for feature films and TV drama are: writer, producer, director and protagonist.

For documentaries: writer, producer and director.

Each role is examined separately for female participation. If there is at least one woman credited in that role, it's counted as female.

If at least 50 per cent of roles are female, the creative team for that project qualifies as at least 50 per cent female.

TOTAL NUMBERS OF PROJECTS ANALYSED - 2013/14 and 2014/15

\begin{tabular}{|l|r|r|}
\hline FUNDING TYPE & APPLICATIONS & $\begin{array}{r}\text { SUCCESSFUL } \\
\text { APPLICATIONS }\end{array}$ \\
\hline Feature development & 249 & 116 \\
\hline Feature production & 82 & 35 \\
\hline Documentaries development & 150 & 94 \\
\hline Documentaries production & 261 & 119 \\
\hline TV drama development & 10 & 6 \\
\hline TV drama production & 27 & 25 \\
\hline
\end{tabular}

Based on funding administered for the indicated programs during 2013/14 and 2014/15.

Notes:

- Roles are at the time of application and do not reflect any subsequent revisions or additions.

- Applications marked withdrawn were excluded.

- Applications that received an LOI or an EOI only were not counted as successful applications.

- PEP projects were excluded as they do not undergo assessment.

\footnotetext{
${ }^{19}$ Statistics are based on data provided at time of application which in some cases may be preliminary or incomplete. While Screen Australia has undertaken all reasonable measures to ensure accuracy, there is a small margin for error.
} 

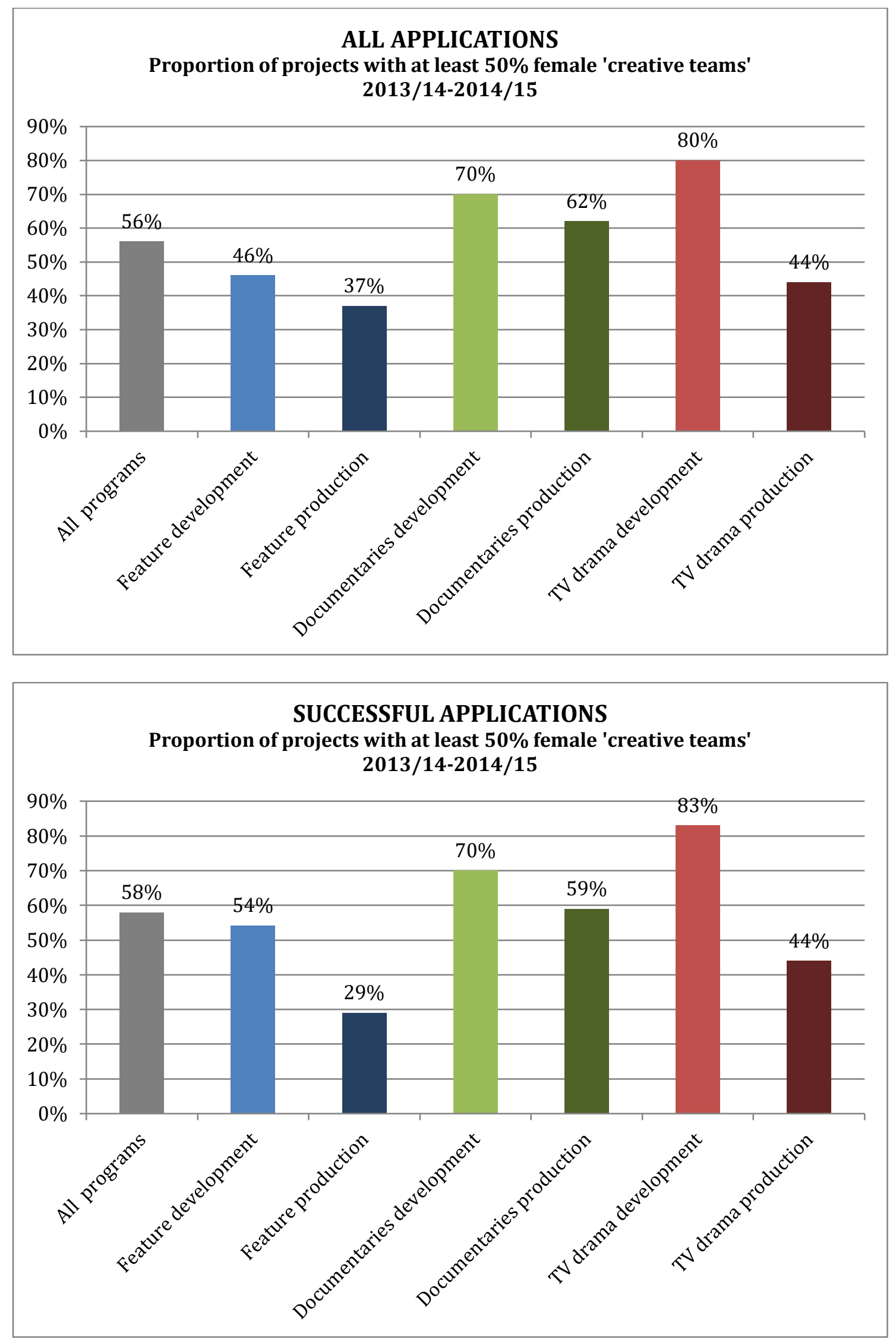


\section{Appendix 2}

\section{Screen Australia Applications and Approvals 2013/14 and 2014/15 20}

These statistics refer to individual practitioners and whether or not they were attached to at least one project that received funding over the two-year period. To clearly track career development, and identify where the problems are, where individuals are attached to two or more projects in the same role, for the same funding program, they are only counted once.

The proportion of female key creatives attached to applications and the proportion that were attached to funded projects was similar. This indicates that Screen Australia does not have a bias against projects with female key creatives. However, there were far fewer female key creatives attached to applications, in particular in the roles of writer and director. It should be noted that the credits on the projects could change from application to completion stage.

\section{Fiction Features - Production Investment}

Female producers were relatively well represented, comprising 40 per cent of applicant producers and 47 per cent of funded producers. Of all Screen Australia funding programs, feature production investment applications had the lowest proportion of female writers and directors.

Women attached to applications

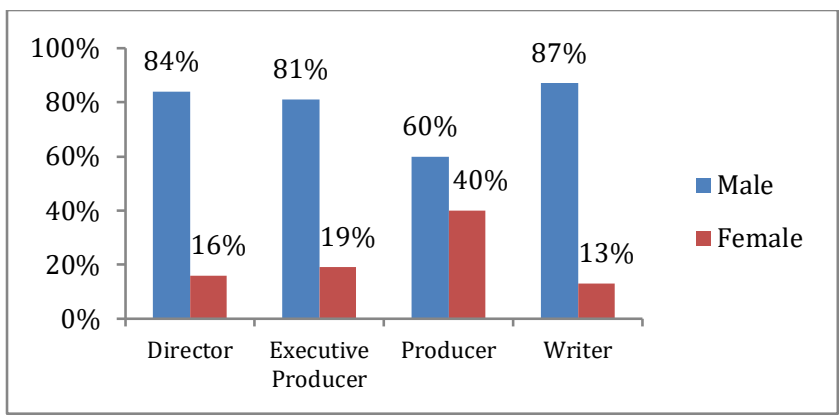

\begin{tabular}{|l|c|c|c|}
\hline Applications & & & \\
\hline & Female & Male & Total \\
\hline Director & 11 & 56 & 67 \\
\hline Executive Producer & 9 & 38 & 47 \\
\hline Producer & 45 & 67 & 112 \\
\hline Writer & 8 & 56 & 64 \\
\hline
\end{tabular}

Women attached to successful applications

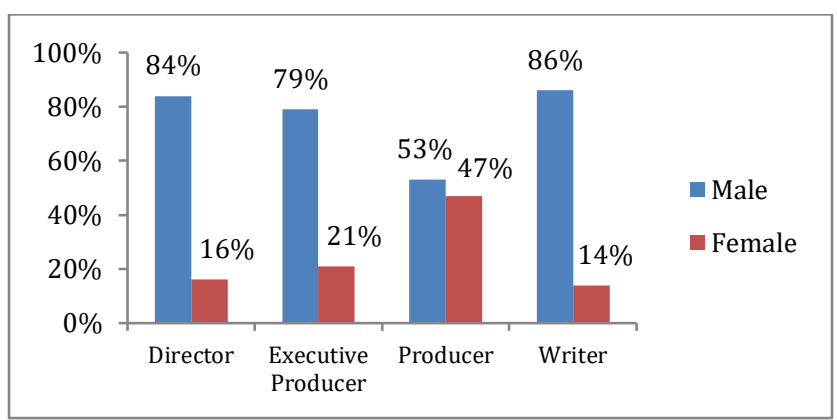

Funded Projects

\begin{tabular}{|l|c|c|c|}
\hline Role & Female & Male & Total \\
\hline Director & 6 & 32 & 38 \\
\hline Executive Producer & 6 & 22 & 28 \\
\hline Producer & 28 & 32 & 60 \\
\hline Writer & 5 & 30 & 35 \\
\hline
\end{tabular}

\footnotetext{
${ }^{20}$ Statistics are based on data provided at time of application which in some cases may be preliminary or incomplete. While Screen Australia has undertaken all reasonable measures to ensure accuracy, there is a small margin for error.
} 


\section{Gender Matters - Women in the Australian Screen Industry}

\section{Feature Development}

The proportion of female key creatives supported through feature development is much higher than the proportion supported through feature production, reflecting the greater number of women attached to applications for development.

\section{Women attached to applications}

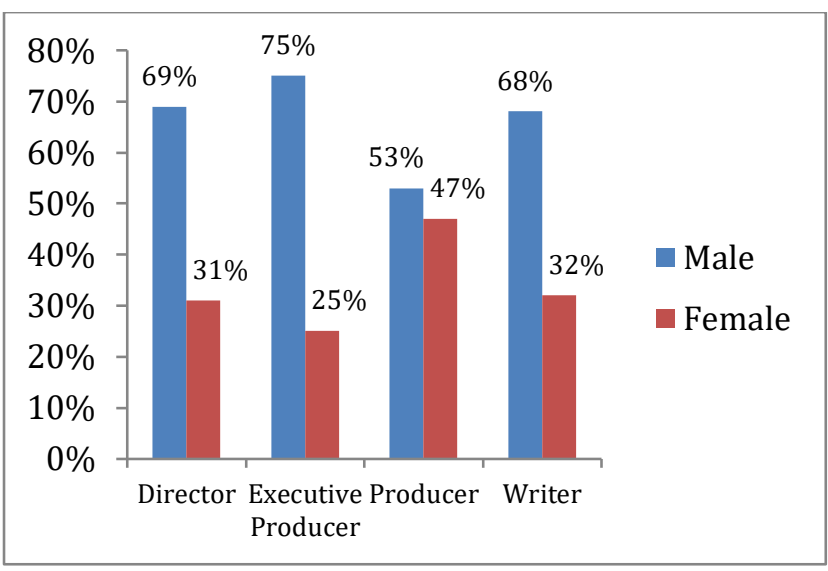

\begin{tabular}{|l|c|c|c|}
\hline Applications & \multicolumn{3}{|c|}{} \\
\hline Role & Female & Male & Total \\
\hline Director & 44 & 98 & 142 \\
\hline Executive Producer & 21 & 57 & 78 \\
\hline Producer & 123 & 139 & 262 \\
\hline Writer & 85 & 180 & 265 \\
\hline
\end{tabular}

Women attached to successful applications

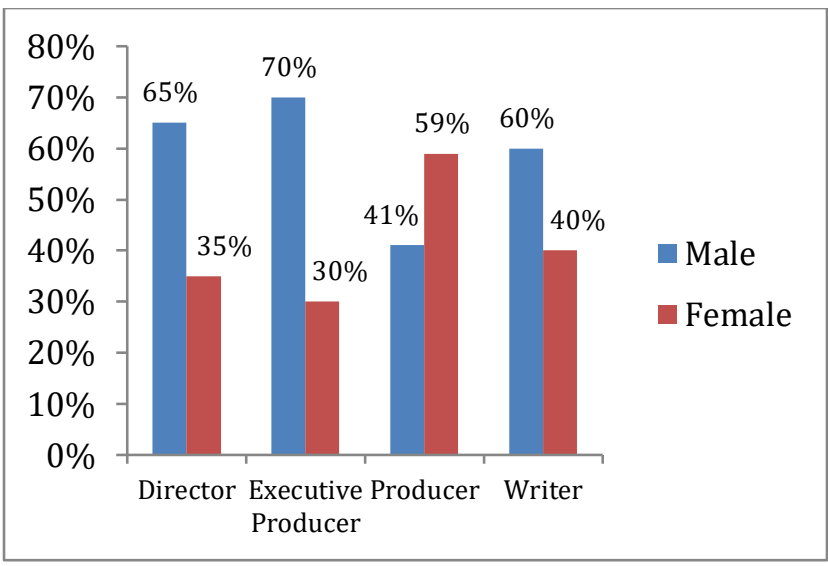

\section{Funded Projects}

\begin{tabular}{|l|c|c|c|}
\hline & Female & Male & Total \\
\hline Director & 25 & 47 & 72 \\
\hline Executive Producer & 12 & 26 & 38 \\
\hline Producer & 68 & 48 & 116 \\
\hline Writer & 46 & 70 & 116 \\
\hline
\end{tabular}

Individuals attached to two or more projects in the same role, for the same funding program, are counted once only. 


\section{Gender Matters - Women in the Australian Screen Industry}

\section{TV Drama (incl. Children's)}

The proportion of female writers and producers was around 35 per cent for both roles. Several projects did not have directors attached at application stage so these statistics cannot be provided.

\section{Women attached to applications}

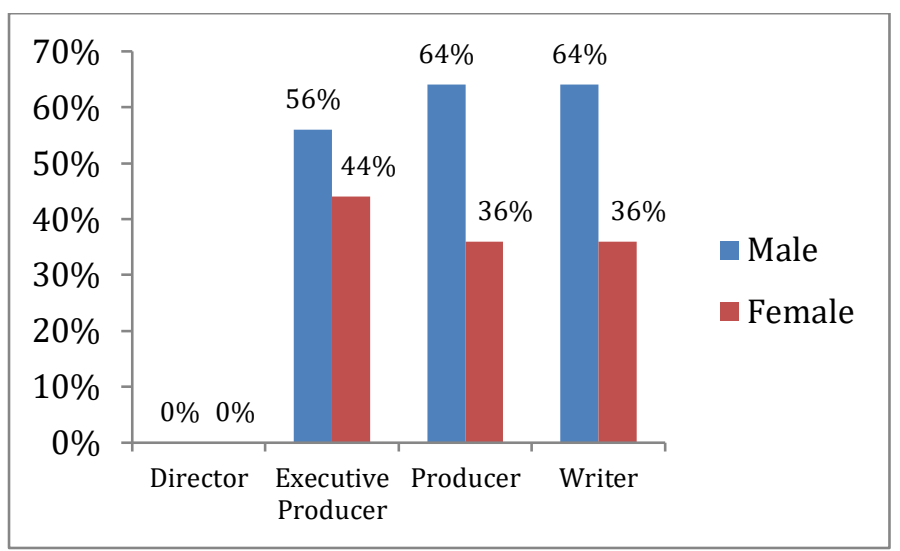

\begin{tabular}{|c|c|c|c|}
\hline & Female & Male & Total \\
\hline Director ${ }^{21}$ & $\mathrm{n} / \mathrm{a}$ & $\mathrm{n} / \mathrm{a}$ & $\mathrm{n} / \mathrm{a}$ \\
\hline Executive Producer & 11 & 14 & 25 \\
\hline Producer & 14 & 25 & 39 \\
\hline Writer & 15 & 27 & 42 \\
\hline
\end{tabular}

Women attached to successful applications

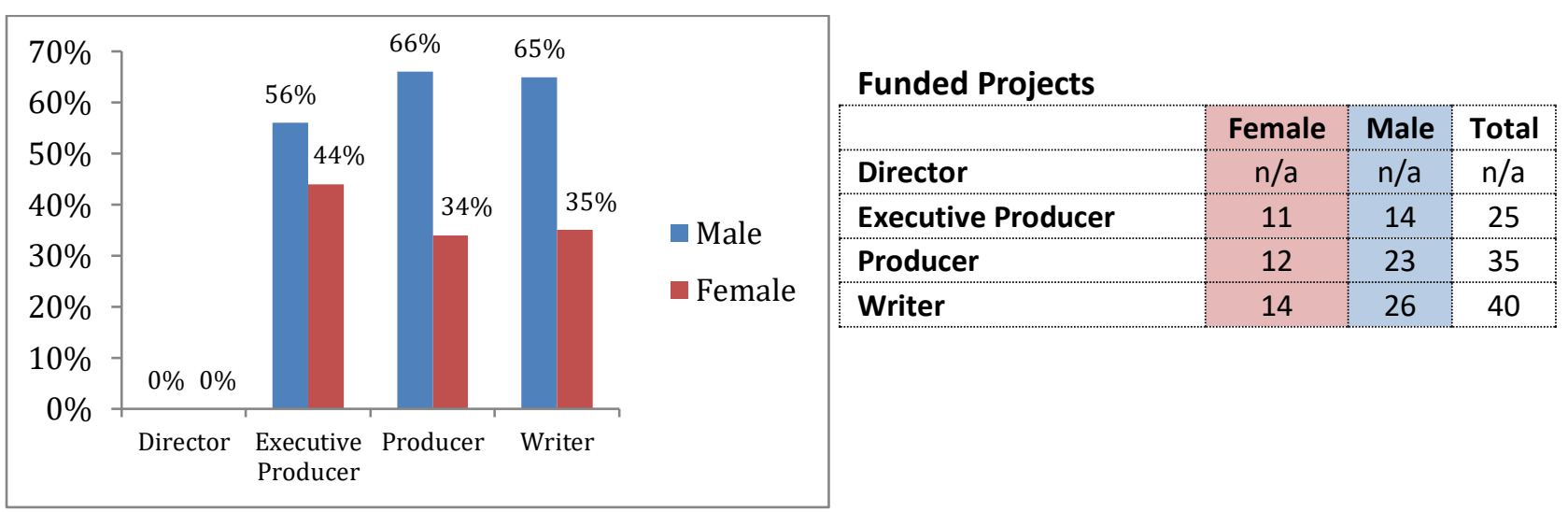

Individuals attached to two or more projects in the same role, for the same funding program, are counted once only.

${ }^{21}$ TV series usually have multiple directors and most projects do not have a complete list of directors attached at development or production funding application stage. 


\section{Gender Matters - Women in the Australian Screen Industry}

\section{Talent Escalator - Hot Shots, Short Film Completion \& Animation Shorts}

In contrast to fiction features, women were well represented across the key creative roles in these short-form projects. Over 60 per cent of producers were women and the proportion of female writers and directors was over 40 per cent for both applications and funded projects.

Women attached to applications

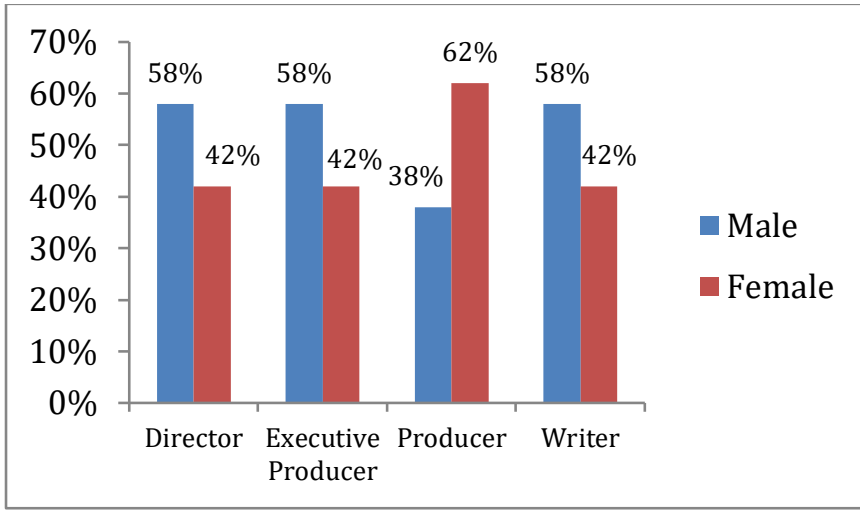

\begin{tabular}{|l|c|c|c|}
\hline Applications & Female & Male & Total \\
\hline Director & 55 & 76 & 131 \\
\hline Executive Producer & 10 & 14 & 24 \\
\hline Producer & 94 & 58 & 152 \\
\hline Writer & 50 & 69 & 119 \\
\hline
\end{tabular}

Women attached to successful applications

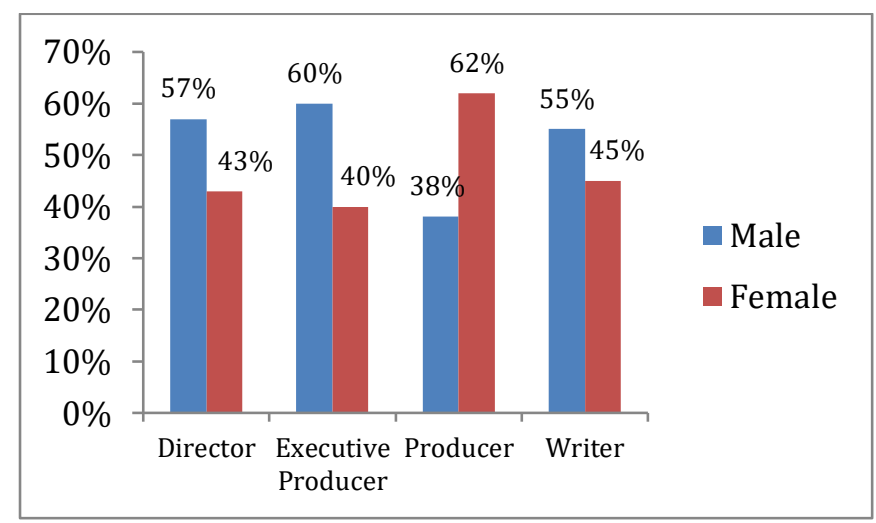

Funded Projects

\begin{tabular}{|l|c|c|c|}
\hline & Female & Male & Total \\
\hline Director & 10 & 13 & 23 \\
\hline Executive Producer & 2 & 3 & 5 \\
\hline Producer & 18 & 11 & 29 \\
\hline Writer & 10 & 12 & 22 \\
\hline
\end{tabular}

Individuals attached to two or more projects in the same role, for the same funding program, are counted once only. 


\section{Gender Matters - Women in the Australian Screen Industry}

\section{Multiplatform (Incl. Skip Ahead)}

For applications and funded projects the proportion of female producers was approximately half. The proportion of female directors and writers was relatively low, however, there has been a recent increase in female key creatives supported through Multiplatform, which is not captured in these statistics.

\section{Women attached to applications}

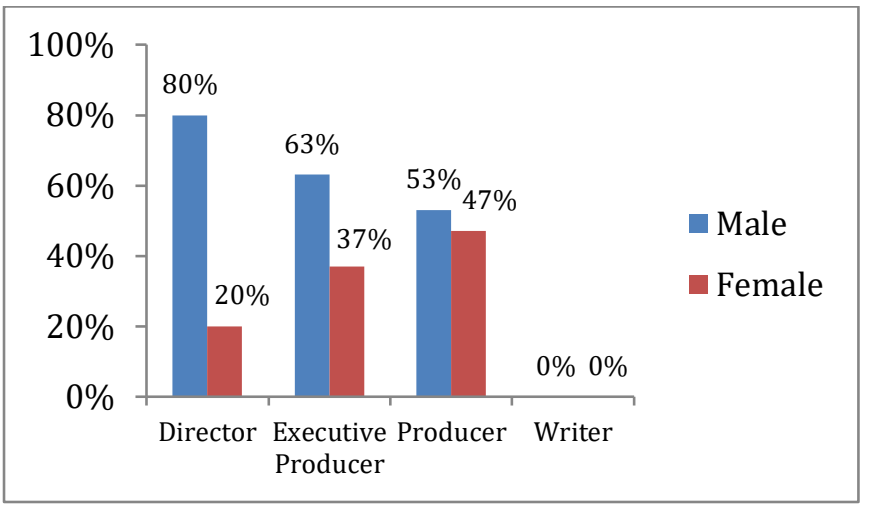

\section{Applications}

\begin{tabular}{|l|c|c|c|}
\hline & Female & Male & Total \\
\hline Director & 12 & 47 & 59 \\
\hline Executive Producer & 11 & 19 & 30 \\
\hline Producer & 36 & 41 & 77 \\
\hline Writer & n/a & n/a & n/a 22 \\
\hline
\end{tabular}

Women attached to successful applications

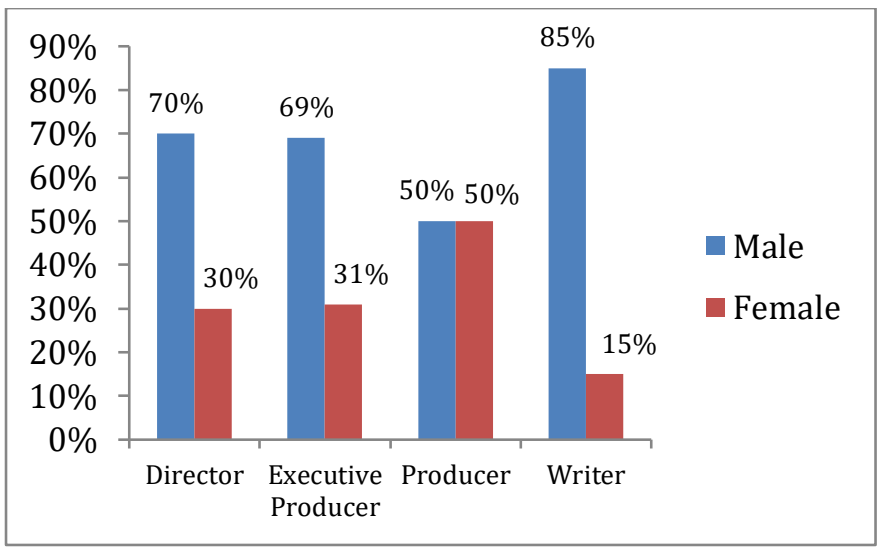

Funded Projects

\begin{tabular}{|l|c|c|c|}
\hline & Female & Male & Total \\
\hline Director & 10 & 23 & 33 \\
\hline Executive Producer & 5 & 11 & 16 \\
\hline Producer & 20 & 20 & 40 \\
\hline Writer & 7 & 41 & 48 \\
\hline
\end{tabular}

Individuals attached to two or more projects in the same role, for the same funding program, are counted once only.

\footnotetext{
22 Many projects do not have a complete list of writers attached at application stage
} 


\section{Gender Matters - Women in the Australian Screen Industry}

\section{Documentary (Incl.features)}

Female producers are well represented amongst the documentary projects supported by Screen Australia. However, the proportion of female directors and writers is lower at 37 per cent and 39 per cent respectively for funded projects.

Women attached to applications

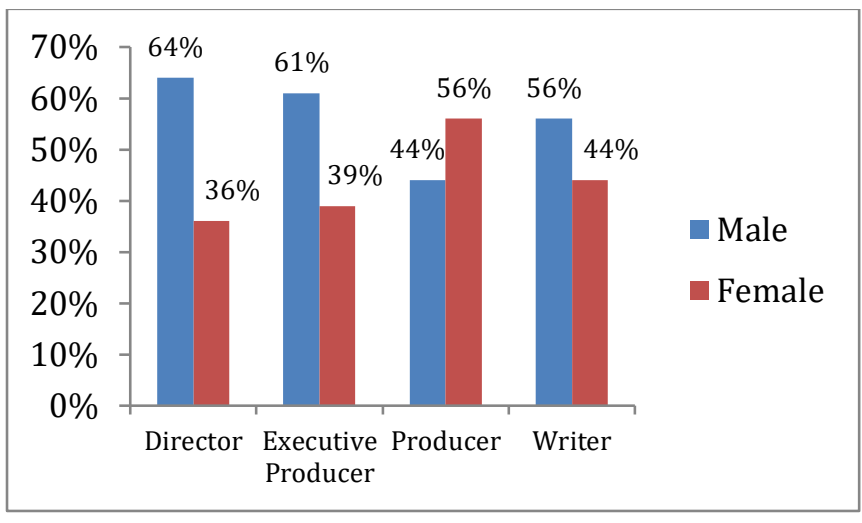

\begin{tabular}{|c|c|c|c|}
\hline & Female & Male & Total \\
\hline Director & 72 & 129 & 201 \\
\hline Executive Producer & 35 & 54 & 89 \\
\hline Producer & 156 & 124 & 280 \\
\hline Writer & 58 & 74 & 132 \\
\hline
\end{tabular}

Women attached to successful applications

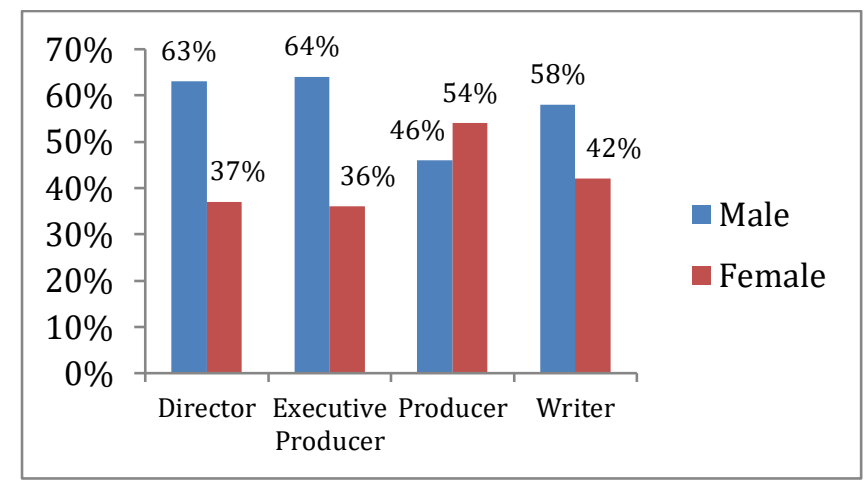

Funded Projects

\begin{tabular}{|l|c|c|c|} 
& Female & Male & Total \\
\hline Director & 47 & 81 & 128 \\
\hline Executive Producer & 24 & 42 & 66 \\
\hline Producer & 102 & 88 & 190 \\
\hline Writer & 41 & 56 & 97 \\
\hline
\end{tabular}

Individuals attached to two or more projects in the same role, for the same funding program, are counted once only. 


\section{Gender Matters - Women in the Australian Screen Industry}

\section{Documentary development}

Similar to feature films, the proportion of female directors is higher for documentary development funding projects than production funding. Women were well represented in key creative roles with the exception of the role of writer, with women comprising approximately 35 per cent of applicants and supported writers.

Women attached to applications

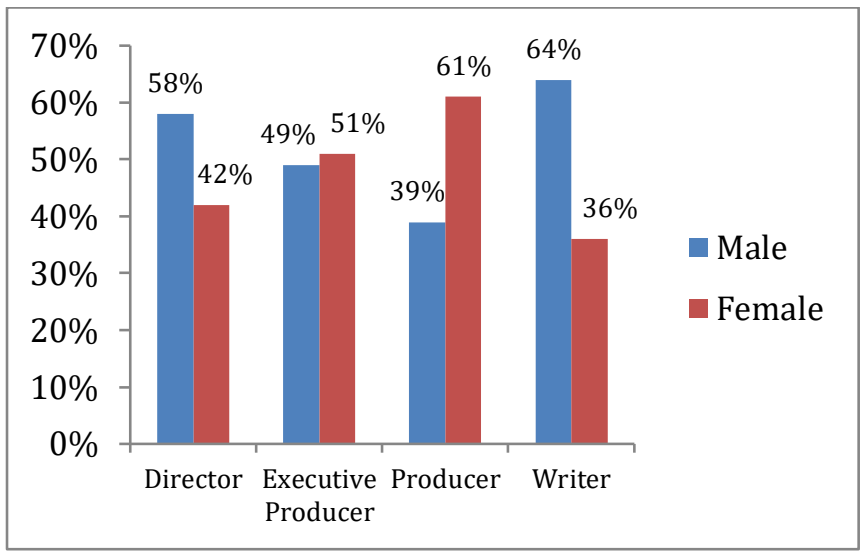

Applications

\begin{tabular}{|l|c|c|c|}
\hline & Female & Male & Total \\
\hline Director & 50 & 68 & 118 \\
\hline Executive Producer & 23 & 22 & 45 \\
\hline Producer & 102 & 66 & 168 \\
\hline Writer & 25 & 44 & 69 \\
\hline
\end{tabular}

Women attached to successful applications

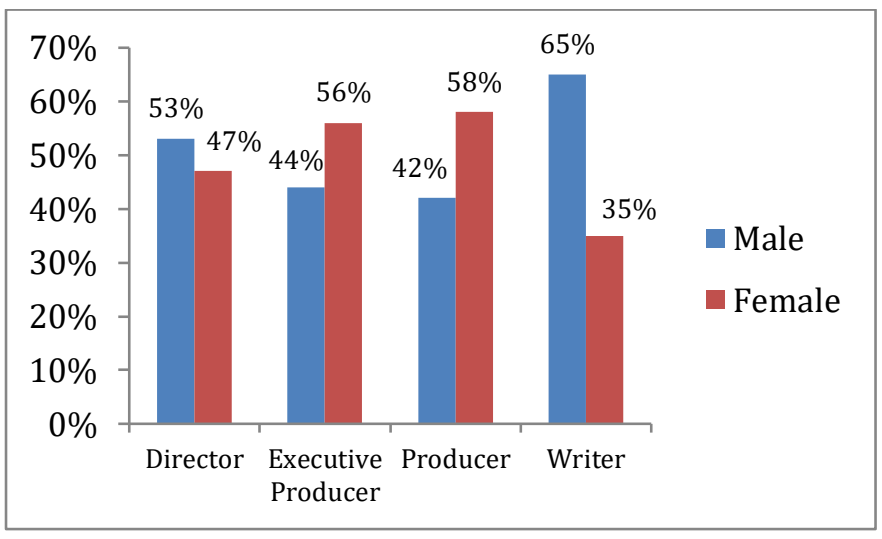

\begin{tabular}{|c|c|c|c|}
\hline & Female & Male & Total \\
\hline Director & 36 & 40 & 76 \\
\hline Executive Producer & 15 & 12 & 27 \\
\hline Producer & 67 & 48 & 115 \\
\hline Writer & 18 & 33 & 51 \\
\hline
\end{tabular}

Individuals attached to two or more projects in the same role, for the same funding program, are counted once only. 


\section{Gender Matters - Women in the Australian Screen Industry}

\section{Appendix 3 - International Approaches}

\section{Sweden}

The Swedish Film Institute (SFI) has achieved its 50 per cent funding target for women in key creative roles on feature films in 2014. This has led to calls from industry stakeholders, such as the ADG Affirmative Action sub-committee, for Screen Australia to introduce a 50 per cent target. However, there are significant differences between how SFI and Screen Australia work with industry and fund feature films, especially in the area of marketplace support, which would need to be taken into account when comparing funding outcomes.

It is also important to look at the impact beyond the target of films being financed and produced, such as the audience reach and impact of Swedish films directed by women and career progression for female key creatives. If Screen Australia were to adopt this funding method, it would require a complete overhaul of the criteria currently used to assess applications, including less emphasis on marketplace support, which would result in greater commercial risk across the slate.

\section{Swedish Film Policy}

Swedish film policy, including the SFI's funding programs, is financed and developed in accordance with an agreement (the Film Agreement) between the SFI, the Swedish government, industry bodies and broadcasters, which is renegotiated roughly every five years. ${ }^{23}$ The Agreement is funded by the signatories, including exhibitors, who contribute revenue from a ten per cent levy on cinema tickets. The Swedish government also contributes funding to the Agreement. This model of film policy development and funding is unique to Sweden and has been in place since 1963.

Clear gender equality objectives have been included in the Film Agreement since 2006. ${ }^{24}$ The 2006 Film Agreement included a 40 per cent target for funding directed towards films with women in key creative roles, ${ }^{25}$ and was increased to 50 per cent in the 2013 Agreement. ${ }^{26}$ It should be noted these are not guaranteed going forward as the Film Agreement will terminate in January 2017, to be replaced by a new Film Bill (see page 29).

The 2013 agreement, which runs until 31 December 2016, includes the directives:

\footnotetext{
${ }^{23}$ http://www.filminstitutet.se/en/about-us/swedish-film-institute/mission-and-organisation/the-filmagreement/

${ }^{24}$ WIFT Sweden, 2013, What a Sad Story! Production, Distribution and Gender Equality in the Swedish Film Industry http://www.filmdirectors.eu/wp-content/uploads/2014/11/A-Real-Tear-Jerker-WIFT-14.pdf

${ }^{25}$ www.filminstitutet.se/globalassets/4.-om-oss/svenska-filminstitutet/engelsk-media/the-2006-filmagreement.pdf

${ }^{26} \mathrm{http}: / /$ www.filminstitutet.se/globalassets/4.-om-oss/svenska-filminstitutet/engelsk-media/the-2013-filmagreement.pdf
} 


\section{Gender Matters - Women in the Australian Screen Industry}

- Funding shall be distributed so as to create the best possible conditions for a modern, vigorous and independent film production and film industry, so that cyclical circumstances can be managed and necessary finance obtained;

- Funding shall be divided evenly between women and men;

- Funding shall be given based on the perspective of diversity.

The aim of the gender equality directive is that production funding is divided equally between women and men in the categories of scriptwriter, producer and director. This target applies separately to production funding for feature film, children's films, short film and documentary. The gender target does not apply to the 'automatic funding' program and was not met by all funding programs in 2014.

The diversity directive refers to the following types of diversity:

- Perspectives: class, gender, age, ethnicity, agenda, social values, sexuality, LGBT, experience, ideology

- Genres: diversity of expression, form, appeal, aesthetics, model

- Gender: protagonist, roles behind the camera, target audience

- Values: Reflecting the age in which we live

\section{SFI Feature Film Funding Streams}

The Swedish Film Institute has two types of funding for feature films, which are drawn from the same pool of money: production funding and automatic funding. The gender target only applies to films that receive production funding. In 2013, the SFI took 25 per cent of the production funding program budget to create a separate support program for market-let films, under the 'automatic funding' stream. Films receive 'automatic funding' if they have a distributor attached and 70 per cent of the budget in place. In contrast, 'production funding' films undergo qualitative assessment by one of the SFI's film commissioners. ${ }^{27}$

While 50 per cent of the films that received production funding in 2014 had a female director, only 17 per cent of the films that received automatic funding had a female director. ${ }^{28}$

Films receive 'automatic funding' without qualitative assessment if they meet a number of conditions $^{29}$ :

- SFI funding must represent no more than 30 per cent of the budget

\footnotetext{
27 WIFT Sweden, 2013, What a Sad Story! Production, Distribution and Gender Equality in the Swedish Film Industry http://www.filmdirectors.eu/wp-content/uploads/2014/11/A-Real-Tear-Jerker-WIFT-14.pdf

${ }^{28}$ Swedish Film Institute, Facts \& Figures 2014 http://www.filminstitutet.se/en/learn-more-aboutfilm/statistics/facts--figures/

${ }^{29}$ WIFT Sweden, 2014, What a Sad Story! Distribution, Production and Gender Equality in the Swedish Film Industry
} 


\section{Gender Matters - Women in the Australian Screen Industry}

- A minimum budget of SEK 14 million (AUD 2.3 million)

- Multiple independent financiers, including a Swedish TV network

- Financing from a distributor

- Financing from outside the film industry

- A projected cinema attendance by the distributor of at least 250,000

\section{Average financing 2014}

Films that receive 'production funding' have far less marketplace support than films that go through the 'automatic funding' program, for example in 2014 distributors contributed on average 2 per cent of the budget for 'production funding' films and 25 per cent of the budget for 'automatic funding' features.

Production Funding - 14 Fiction Features

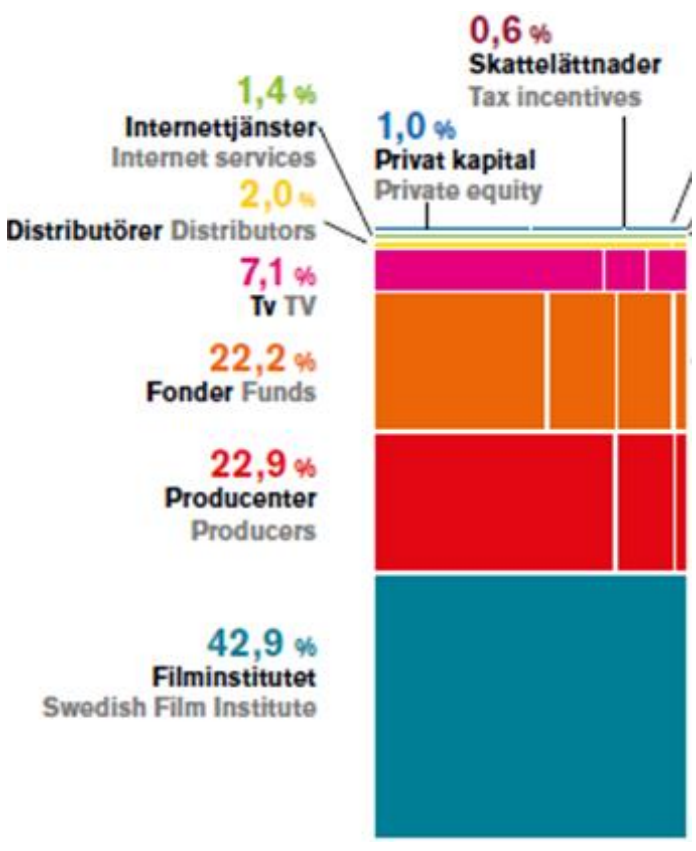

Automatic Funding - 6 Fiction Features

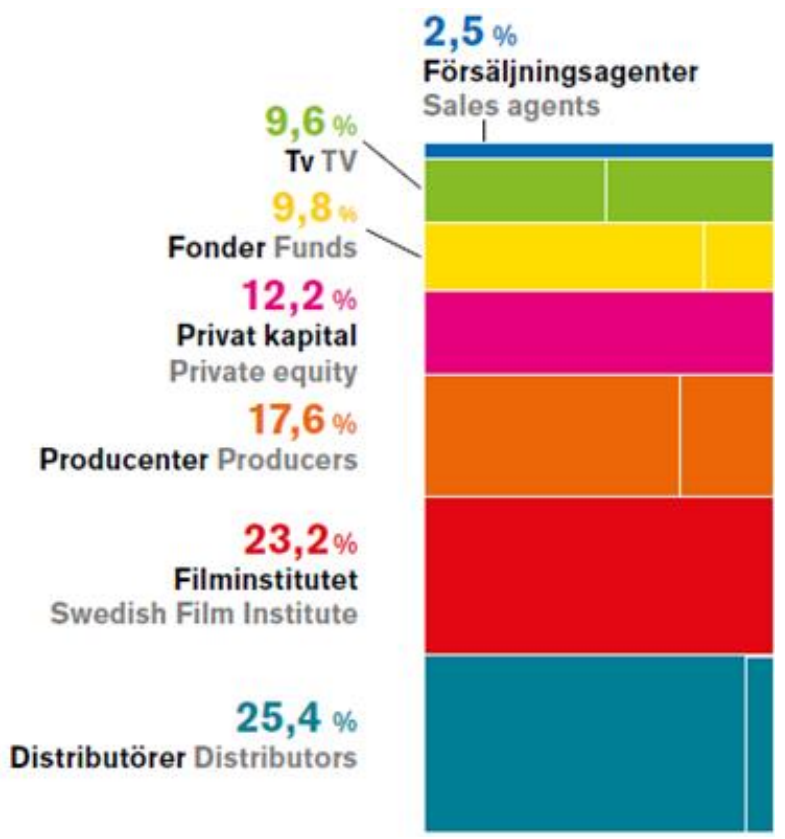

In contrast, Screen Australia requires feature films to have significant marketplace support, including a distributor attachment, to be eligible for production funding. There is no international precedent for putting a gender target on funding for films with a distributor attachment. Any target for funding female creatives would require widespread support from industry to be achievable in Australia.

\section{Broader impact of the target}

The proportion of Swedish films released in cinemas that are directed by women remains low. In 2014, 18 per cent of Swedish films released theatrically had a female director, 36 per cent a female 


\section{Gender Matters - Women in the Australian Screen Industry}

screenwriter and 30 per cent a female producer ${ }^{30}$. Between 2010 and 2014, the proportion of Swedish films released that had a female director fluctuated from a low of 7 per cent in 2013 and a high of 30 per cent in $2011^{31}$. Swedish films directed by men have far greater reach and impact. For example, only one of the top ten highest grossing Swedish films in 2014 was directed by a woman and all of the top five were directed by men. ${ }^{32}$

\section{Sweden's Five Point Plan}

In addition to a gender equality directive for direct investment, the Swedish Film Institute has implemented a five-point plan to foster the participation and career progression of women in the film industry.

- The SFI has set up a website to promote women filmmakers in the Nordic region: Nordic Women in Film http://www.nordicwomenfilm.com/Om.aspx

- A mentoring program, Moviement, which pairs 5 established female film directors with 10 female directors with one feature film credit. The program is a leadership and strategy course which aims to empower female directors in taking their film ideas through the funding labyrinth to finished film.

- The SFI has upgraded the ongoing monitoring of its funding, in order to reveal what works towards creating a more gender-equal film industry.

- Initiatives to highlight role models and mentors for young women who show an interest in the film profession in their teens. In addition, projects to strengthen equality in areas such as film schools, film festivals, competitions and regional talent development.

- A research project with the Swedish Film \& TV Producers Association and research from the Royal Institute of Technology to study the structures that exist within the industry

\section{New policy}

In May 2015, the Swedish government announced that it would terminate the Film Agreement and would instead take sole responsibility for Sweden's film policy. The Film Bill will be submitted to Swedish Parliament in 2016, and the new film policy will come into force on 1 January 2017. The Film Agreement has financed and governed parts of state film policy since 1963.

\footnotetext{
${ }^{30}$ Swedish Film Institute, Facts \& Figures 2014 http://www.filminstitutet.se/en/learn-more-aboutfilm/statistics/facts--figures/

${ }^{31}$ Swedish Film Institute, Facts \& Figures 2014 http://www.filminstitutet.se/en/learn-more-aboutfilm/statistics/facts--figures/

32 Swedish Film Institute, Facts \& Figures 2014 http://www.filminstitutet.se/en/learn-more-aboutfilm/statistics/facts--figures/
} 


\section{Gender Matters - Women in the Australian Screen Industry}

The move to scrap the Film Agreement has been widely supported by industry stakeholders. The Film Agreement had been criticised for failing to adapt to industry shifts and changing audience behaviour. ${ }^{33}$ Sweden's Culture Minister Alice Bah Kuhnke has stated that the new policy would be 'more technology neutral' and would involve a 'better balance between the artistic and commercial interests of the film industry'. It has not yet been announced what gender equality measures will be included in the new film policy.

\section{Statistics}

Gender statistics: Proportion of funded films in 2014 with a woman as ... ${ }^{34}$

\begin{tabular}{|l|l|l|l|}
\hline Funding Program & Director & Screenwriter & Producer \\
\hline Feature fiction - Production & $50 \%$ & $61 \%$ & $69 \%$ \\
\hline Feature fiction - Automatic & $17 \%$ & $33 \%$ & $42 \%$ \\
\hline Feature doc & $47 \%$ & $47 \%$ & $38 \%$ \\
\hline Short fiction & $42 \%$ & $44 \%$ & $52 \%$ \\
\hline Short doc & $55 \%$ & $56 \%$ & $61 \%$ \\
\hline $\begin{array}{l}\text { Moving Sweden (30, 45 \& 60 } \\
\text { min fiction films) }\end{array}$ & $29 \%$ & $44 \%$ & $38 \%$ \\
\hline
\end{tabular}

\begin{tabular}{|c|c|c|c|c|c|}
\hline & 2010 & 2011 & 2012 & 2013 & 2014 \\
\hline \multicolumn{6}{|c|}{ Production funding (funded by a SFI film commissioner) } \\
\hline No. of films & 18 & 21 & 23 & 13 & 14 \\
\hline \% directed by a woman & $33 \%$ & $29 \%$ & $32 \%$ & $38 \%$ & $50 \%$ \\
\hline \multicolumn{6}{|l|}{ Automatic funding } \\
\hline No. of films & - & - & - & 5 & 6 \\
\hline$\%$ directed by a women & - & - & - & $0 \%$ & $17 \%$ \\
\hline
\end{tabular}

\footnotetext{
${ }^{33} \mathrm{http}: / /$ www.nordiskfilmogtvfond.com/index.php/news/stories/swedish-industry-welcomes-governmentsplan-axe-film-policy/

${ }^{34}$ Swedish Film Institute, Facts \& Figures 2014 http://www.filminstitutet.se/en/learn-more-aboutfilm/statistics/facts--figures/

${ }^{35}$ Swedish Film Institute, Facts \& Figures 2014 http://www.filminstitutet.se/en/learn-more-aboutfilm/statistics/facts--figures/
} 
Gender Matters - Women in the Australian Screen Industry

\begin{tabular}{|l|l|l|l|l|l|}
\hline Total - All funded features \\
\hline Number & 18 & 21 & 23 & 18 & 20 \\
\hline$\%$ directed by a woman & $33 \%$ & $29 \%$ & $32 \%$ & $28 \%$ & $40 \%$ \\
\hline
\end{tabular}

First time directors

The 'production funding' program supports a greater proportion of first time directors. ${ }^{36}$

\begin{tabular}{|l|l|l|l|l|l|}
\hline & $\mathbf{2 0 1 0}$ & $\mathbf{2 0 1 1}$ & $\mathbf{2 0 1 2}$ & $\mathbf{2 0 1 3}$ & $\mathbf{2 0 1 4}$ \\
\hline $\begin{array}{l}\text { Production } \\
\text { Funding }\end{array}$ & $33 \%$ & $43 \%$ & $26 \%$ & $54 \%$ & $50 \%$ \\
\hline $\begin{array}{l}\text { Automatic } \\
\text { Funding }\end{array}$ & - & - & - & $40 \%$ & $17 \%$ \\
\hline
\end{tabular}

${ }^{36}$ Swedish Film Institute, Facts \& Figures 2014 http://www.filminstitutet.se/en/learn-more-aboutfilm/statistics/facts--figures/ 


\section{Gender Matters - Women in the Australian Screen Industry}

\section{United Kingdom}

\section{Diversity Initiative}

In October 2015, the British Film Institute (BFI) announced a GBP 1 million (AUD\$ 2.15 million)

Diversity Fund to provide support to individuals for professional development and to companies and organisations to show leadership in fostering diversity. ${ }^{37}$ This fund will complement the BFI Diversity Standards, which is an extension of the Three Ticks pilot initiative ${ }^{38}$.

The BFI introduced the Three Ticks initiative in September 2014 to foster diversity in relation to ethnicity or national origins, disability, sexual orientation, age and socio-economic status as well as gender. Three Ticks was a one year pilot to 'stress test' the guidelines and applied to feature film production funding.

The Three Ticks assessment required applicants to meet at least one criterion (one tick) in a minimum of two areas for a project to be eligible for BFI production funding. There were three areas, each with detailed criteria: on-screen diversity, off-screen diversity and creating opportunities and promoting social mobility ${ }^{39}$.

Under the Diversity Standards, applicants are required to demonstrate how their project tackles under-representation across four areas to be eligible for funding. At least one tick is required in a minimum of two areas. Projects are independently assessed against the Diversity Standards by the BFI's Certification Unit, which also administers the cultural test for tax relief.

1. On Screen Representation, Themes \& Narrative

This section considers the representation and recognition of specific groups on screen. For example, is the project telling us something we do not already know? Is it a new voice? Or, a familiar story told from a different POV?

\section{Creative Practitioners \& Artistic Leadership}

Is the artistic leadership of one of the identified diverse groups likely to have a positive outcome on the project? Does the project have the potential to open doors which have historically been closed?

3. Industry Access \& Opportunities

\footnotetext{
37 http://www.bfi.org.uk/news-opinion/news-bfi/announcements/bfi-announces-1m-diversity-fund-alongsidenew-diversity-strands

38 http://www.bfi.org.uk/sites/bfi.org.uk/files/downloads/bfi-film-fund-diversity-guidelines-for-production2014-11.pdf

39 http://www.bfi.org.uk/sites/bfi.org.uk/files/downloads/bfi-film-fund-diversity-guidelines-for-production2014-11.pdf
} 


\section{Gender Matters - Women in the Australian Screen Industry}

The BFI will consider what the value is of the work experience and development opportunities offered. Does the project present an opportunity to work collaboratively with other elements of the industry? Are there wider and deeper career development opportunities to be offered?

4. Opportunities for Audience Development

The BFI's Diversity Standard has only just been finalised, and further details of the Diversity Fund have yet to be released. Screen Australia will monitor the impact of the BFI's diversity initiatives to see if any aspects of the BFI's system could be usefully adapted to the Australian context. 